\title{
YME 海外派遣報告・討論会についで
}

\section{伊 藤 恭 裕 ${ }^{* *}$}

平成 20 年 12 月 16 日に開催された YME 海外派遣報 告・討論会について報告する.

YME（Young Marine Engineer）海外派遣事業には, 「海外調查交流派遣」と「研究集会派遣」とがある。 前者は海外の学会との交流や派遣者の専門領域での海 外研究機関・大学または企業との技術交流を通じて, 国際的人脈と自身の技術力研鑽を目的とするものであ る. 後者は海外で開催されるマリンエンジニアリング に関連する国際研究集会に出席して論文発表を行い, 海外の専門家との討議や意見交換を通じて, 派遣者自 身の専門領域をより進化させるとともに, 交際的視野, 国際感覚を養うことを目的としている. YME 海外派 遣は 2000 年度に第一回を行って以来, 現在まで 9 回を 数え 41 名が利用されたが, 2008 年度からは「海外調 査交流派遣」に限ることとなっている.

今回の報告・討論会は 3 部構成で，第一部は 2007 年度および 2008 年度の派遣者（各 1 名）による報告, 第二部は 3 名の過去の派遣者による「YME 海外派遣 の成果とその後の展開について」をテーマとした報告. 更に第三部では，講演者と会場の聴講者によるこれか らの YME 海外派遣のあり方についての自由討論とし た. また，司会も YME 海外派遣経験者である段智久 氏（2001 年度，神戸大学）にお願いした。

第一部の報告内容は，既に学会誌に掲載（注）され ているので省略し，ここでは第二部，第三部について 報告する.

第二部の報告者は 2000 年度の第一回 YME 海外派遣 者である幅田望氏 (IHI-マリンユナイテッド) を始め, 井上順広氏 (2003 年度, 東京海洋大学), 川原秀夫氏 (2005 年度, 大島商船高専) の三氏である．第二回以 降の YME 海外派遣は個別派遣であるが，第一回のみ は幅田氏を含め計 5 名の異業種 YME による団体行動 であり，他の YME 派遣とは事情が異なる.

三氏ともに貴重な経験であったこと，そしてその経 験が以降の業務に少なからず生かされているとして, YME 海外派遣の趣旨は十分果たされている, と報告 された。

\footnotetext{
*原稿受付 平成 21 年 1 月 14 日.

**正会員 新潟原動機（株）（中央区八重洲二丁目 9-7）.
}

特に，個別派遣で海外の大学での調査，交流を行っ た井上，川原両氏の場合は，その後も派遣先との交流 が続き, 共同研究や海外留学へと発展するなどの成果 が報告された。一方，団体行動であった幅田氏の場合 は, 派遣先との交流もさることながら，いわゆる YME 海外派遣同期生としての横のつながりが続いているこ との報告があった．後者のケースは YME 海外派遣の 趣旨からすれば副次的なものであるが，若手技術者の 連帯感, 学会事業への参加意識高揚による学会の活性 化という観点では大きな意義がある.

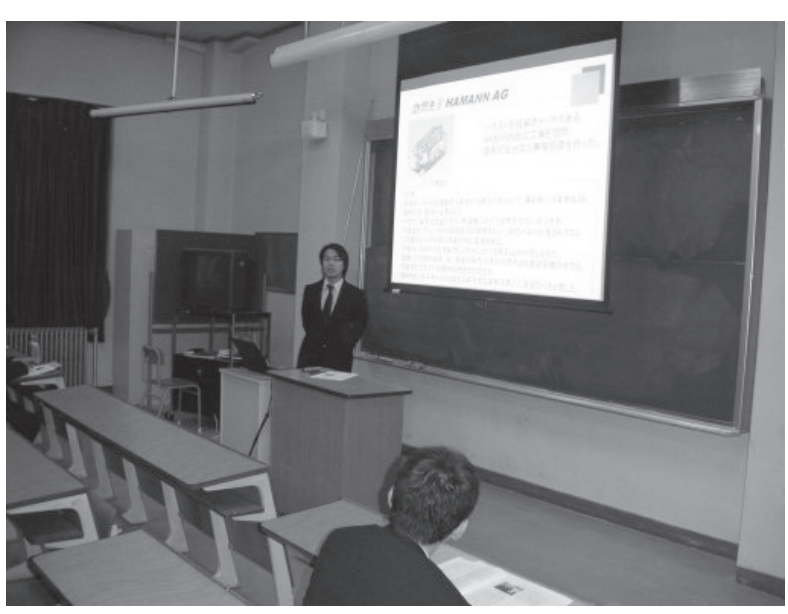

図 1 報告会の模様

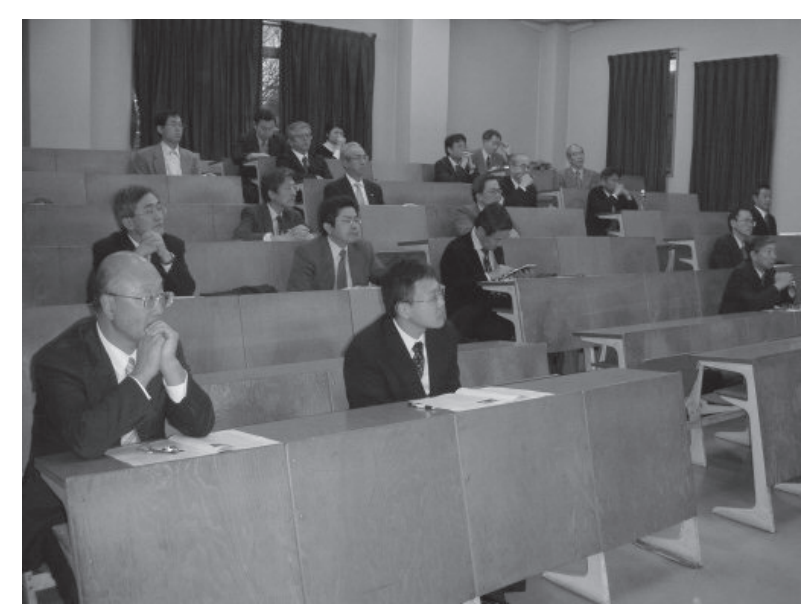

図 2 会場の模様 
第三部では，講演者および会場の聴講者から多くの 意見が出され，終了時刻が気になるほどであった。

YME 海外派遣経験者は異口同音にその成果を述心 ていたが,一方で, そもそものきっかけは外部（上司， 教官など）からの働きかけによる場合が多く，YME 海外派遣事業の存在が，対象となる年代の会員に知ら れていないことの問題提起があった。 団体行動か個別 派遣かも大きな議論となり，それぞれの長所・短所に ついて多くの意見が出された. また，予め学会で派遣 のテーマを決め, その趣旨に沿った派遣形態, 派遣者 および派遣先を決めるべき，との意見も出された。

YME 海外派遣は当初は日本財団の援助で始まった ものであるが，2005 年度からは 100\%学会負担で行わ れている. 時代の要請によりその内容は変化してきた が，学会の事業としての今後のあり方は重要なテーマ である、今回の報告・討論会で出されたご意見は，今 後国際交流委員会で検討することにするが，少なくと も会場の総意としては今後も継続すべしとの結論であ った.

奇しくも2009年度は 10 年目に当たる。ここで一区 切りとし, 新しい形での YME 海外派遣に向けて検討 を開始するに相応しい貴重な報告・討論会であった。

最後に，年末の多忙な時期にも関わらずご出席頂い
た講演者，聴講者および開催にご協力頂いた東京海洋 大学ならびに学会関係者の方々に心よりお礼を申し上 げます。

2007 年度 YME 海外派遣報告 (藤野俊和氏, 43 巻 1 号) 2008 年度 YME 海外派遣報告 (湯浅俊哉氏, 44 巻 1 号)

\section{著者紹介}

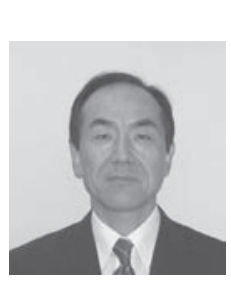

伊藤 恭裕

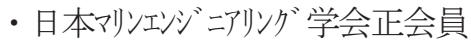

- 1948 年生.

- 所属. 新潟原動機株式会社

・最終学歴. 東北大学工学部

・専門分野. ディーゼルエンジン ガスエンジン

・国際交流委員会委員長

\section{年末懇談会の写真}

YME海外派遣報告会・討論会に続き, 恒例の年末懇談会を東京海洋大学 越中島キャンパス 職員会館にて, 開催いたしました。その時の写真を掲載します。(平成 20 年 12 月 16 日 (火) 18:00～20:00)
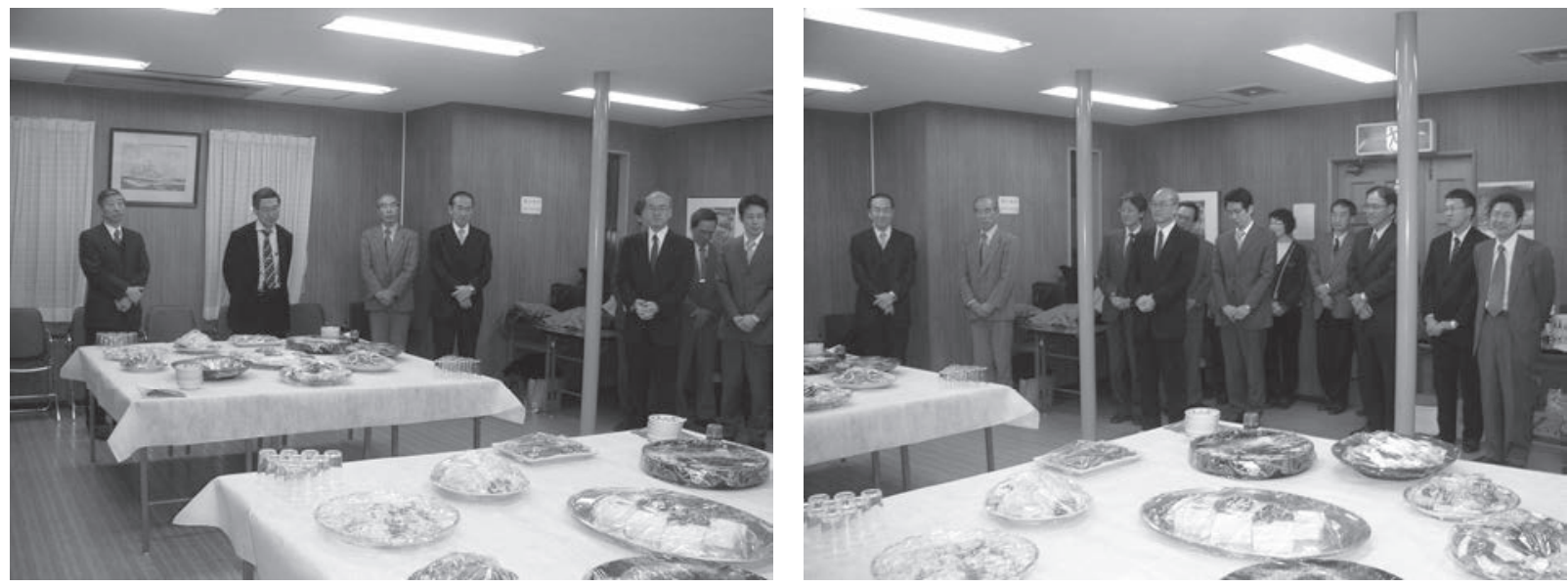